\title{
An Analysis of Religious Tourist Growth in Nepal
}

\author{
Deo Narayan Sutihar*
}

\begin{abstract}
This article attempts to estimate annual growth rate of religious tourist to total tourist arrival ratio in Nepal, test the significance of annual growth rate of this ratio and evaluate the presence of auto-correlation among error terms using time series data of the ratio of religious tourist to total tourist arrival in Nepal from 1992 to 2010. The calculation of t-statistic exhibits that the growth rate of religious tourist to total tourist arrival ratio is significant. The $D-W$ test shows that there is existence of positive autocorrelation among error terms. To remove the auto-correlation, the transformed variables have been used to estimate transformed equation of straight line and then it is found that there is no existence of auto-correlation among error terms after transforming the original data.
\end{abstract}

Keywords: Religious tourist, growth rate, auto-correlation, transformed variable.

\section{INTRODUCTION}

In many countries tourism has become the largest single earner of foreign exchange. The promotion of tourism in Nepal in the true sense started more or less only from the beginning of the 1960's. Since the First Five Year Plan and onwards the government of Nepal has been adopted an integrated approach of increasing the number of tourists arrivals and length of stay, earning exchanges, creating employment opportunities, sustainable economic growth, alleviation of poverty and reduction of regional imbalances through tourism (Gurung, 2010:106).

Tourism is an important industry and it is gaining a growing recognition in the world. It is smokeless industry. Developed countries have already benefited from tourism while developing countries are gradually benefiting. Tourism industry generates substantial benefits for both host countries and tourist's home country. It is the main source of foreign exchange earning and an important factor in the development of industries and international trade. It plays an important role in economic and technological development of nations. It also serves to stimulate the development of basic infrastructure, contributes to the growth of domestic industries, attracts foreign investment, facilities the transfer of technology and information (Srivastava and Baral, $2010: 1-2$ ).

Most of the tourists arriving to Nepal are found to pursuing recreation, trekking and mountaineering. On the tourists visiting Nepal in calendar year 2011, 53.7 percent visited for tours/travels, 11.77 percent for

\footnotetext{
${ }^{*}$ Mr. Sutihar is Associate Professor of Economics, Prithvi Narayan Campus, T.U., Pokhara.
} 
An Analysis of Religious Tourist Growth ..../21

trekking/ mountaineering, 8.7 percent for pilgrimage, 4.1 percent for recreation, 2.4 percent for trade, 3.3 percent for formal visit, 1.5 percent for meeting/seminar and 13.9 percent for other purposes (MoF, 2069 :148).

The contribution of tourism industry to GDP was 3.6 percent in 1992 and 1.4 percent in 2008 (Economic Survey, 2009 : 112), which was reached to 1.8 percent in 2011 (MoF, $2069: 152$ ).

Ministry of Tourism and Civil Aviation, in collaboration with concerned industry entrepreneurs, and Nepal Tourism Board, has issued Nepal Tourism Vision 2020. Under this, vision, target, objectives and strategies have been set to attract 2 million tourists in 2020 (MoF, 2009 : 111).

Nepal is a small country but full of diversities regarding natural, cultural, ethnic communities and historical heritages, which attract religious, sports, endemic tourists to visit. It is a tourist destination with tremendous tourism potentialities. The relevant literature regarding the growth rate religious tourist to total tourist arrival ratio in Nepal has not been conducted. However, some scattered studies have exhibited dim glimpse (Poudyal, 2012 ; Upadhyay, 2013 ; Gurung, 2010 ; Sharma, 2013 ; Shakya, 2008 ; Upreti and Upadhyay, 2013 ;Adhikari, 2069 ; Thapa, 2012) about the very cotext.

The main objective of this article is to show the growth rate of religious tourist to total tourist arrival ratio in Nepal. Similarly, it aims to estimate annual rate of growth of this ratio and to test this rate of growth is significant or not. Likewise, it also aims to test the existence of auto-correlation among error terms and if so, it targets to remove auto-correlation by using transforming the data. The study is very much helpful to those who want to get knowledge about statistical estimation of a variable related to time series and to use statistical tools. Notwithstanding, the findings of this paper should be cautiously and reckfully used because the analysis is made only for 19 years. The data before 1992 have not been considered to analyze due to time constraint.

\section{DATA AND METHODS}

This article is based on the secondary data annually published by the Government of Nepal. The Economic Survey Fiscal Year 2008/09 and Fiscal Year 2068/69 of Nepal are the only sources of tapping statistical data for this study (Table 1).

The data have been analyzed with the help of different statistical tools like ratio, percentage, linear equation for estimating the annual growth rate of religious tourist to total tourist arrival ratio, its standard error, significance of this ratio through $\mathrm{t}$-statistic and coefficient of determination $\left(\mathrm{r}^{2}\right)$. Likewise, the existence of auto-correlation has been evaluated by using D-W statistic, if so the original data has been transformed to remove the auto-correlation.

The estimating linear equation of the religious tourist to total tourist arrival ratio in Nepal of 19 years from 1992 to 2010 has been used in form of $Y=\alpha+\beta X$ (Singh, Parashar and Singh, 1977 : 66), where, $Y=$ religious tourist to total tourist arrival ratio, $X=$ time variable, $\alpha$ and $\beta=$ parameters, $\alpha$ stands for $\mathrm{Y}$-intercept and $\beta$ for annual growth rate of religious tourist to total tourist arrival ratio. 
For these parameters, two normal equations of least squares method have been used, $\sum Y=n \alpha+\beta \sum X$ and $\sum X Y=\alpha \sum X+\beta \sum X^{2}$ $S_{y x}=\sqrt{\frac{\sum e^{2}}{n-k}}$ has been used to arrive standard error of estimate, where, $n$ and $k$ stand for number of years and number of parameters respectively. The statistical hypothesis for parameter $\beta$ has been set up and tested. The t-statistic has been used to test the significance of this parameter. The null and alternative hypotheses for parameter $\beta$ have been tested for the significance of growth rate of religious tourist to total tourist arrival ratio. Null hypothesis $\mathrm{H}_{0}: \beta=0$, i.e. growth rate of religious tourist to total tourist arrival ratio is not significant at 5percent level of significance with $n-k$ degrees of freedom against the alternative hypothesis $\mathrm{H}_{1}: \beta \neq 0$, i.e., the growth rate is significant. The t-test has been used for significance of growth rate of religious tourist to total tourist arrival ratio by using following method:

$$
\mathrm{t}=\frac{\beta}{\sqrt{\frac{\sum \mathrm{e}^{2}}{\mathrm{n}-2}\left(\frac{1}{\sum \mathrm{x}^{2}}\right)}}, \sum \mathrm{e}^{2}=\sum(\mathrm{Y}-\hat{\mathrm{Y}})^{2} \text { (Sum of error squares) and } \sum \mathrm{x}^{2}=\sum \mathrm{X}^{2}-\mathrm{n} \bar{X}^{2}
$$

The coefficient of determination $r^{2}$ has also been computed.

The first order coefficient of auto-correlation has been calculated to find out the existence of autocorrelation among error terms and defined as: $\rho=\frac{\sum_{i=2}^{t} e_{t} e_{t-1}}{\sum_{i=1}^{t} e_{t}{ }^{2}}$. To test the existence of auto-correlation among error terms D-W test has been used developed by J.M.Durwin and G.S.Watson in 1950. They had tested the hypothesis of non-autocorrelation i.e., $\mathrm{H}_{0}: \rho=0$ against the alternative hypothesis of positive autocorrelation of first order i.e., $H_{1}: \rho=\geq 0$. They gave formula for calculation of Durwin-Watson statistics named as 'd' and defined as: $d=\frac{\sum_{i=2}^{t}\left(e_{t}-e_{t-1}\right)^{2}}{\sum_{i=1}^{t} e_{t}^{2}}$, where, $\mathrm{e}_{\mathrm{t}}$ stands for error terms.

To remove the auto-correlation, data have been transformed from given variables ( $\mathrm{X}$ and $\mathrm{Y}$ ) into new variables $\left(X^{\prime}\right.$ and $\left.Y^{\prime}\right)$ as follows:

$X_{n}^{\prime}=X_{n}-\rho X_{n-1}$ and $Y_{n}^{\prime}=Y_{n}-\rho Y_{n-1}$ and then the estimated equation reduces as $Y^{\prime}=\gamma+\delta X^{\prime}$, where, $\gamma$ and $\delta$ are regression parameters of transformed data.

\section{RESULTS AND DISCUSSION}

The present study evaluates the growth rate of religious tourist to total tourist arrival ratio in Nepal, which ranges from 1.0 percent in 1997 to 16.8 percent in 2010. The ratio has been fluctuated in different 
years. This annual growth rate has been estimated through the analysis of time series data of 19 years from 1992 to 2010. The estimated equation of straight line is $\hat{Y}_{t}=-1.6+0.8 X_{t}$, which shows that annual growth rate of religious tourist to total tourist arrival ratio in Nepal is 0.8 percent during study period (Table-1). The growing trend of religious tourist to total tourist arrival ratio exhibits the religious tourist arrival in Nepal is increasing continuously during study period (Fig.1).

It is apparent from the t-test that the growth rate of religious tourist to total tourist arrival ratio is significant, since calculated value of $t=76.19$, which is greater than critical value of $t=2.11$ (Two tailed test) at 5 percent level of significance with 17 degrees of freedom. This comprises that null hypothesis is rejected and alternative hypothesis is accepted. Therefore, it is concluded that annual growth of religious tourist to total tourist arrival ratio is significant. The coefficient of determination exhibits that 72.89 percent of the total variation in growth rate of religious tourist to total tourist arrival ratio is explained by the variation in time variable.

Table 1: Ratio of Religious Tourist to Total Tourist Arrival in Nepal ( in \%)

\begin{tabular}{|l|l|l|l|l|l|l|l|}
\hline Year $\left(\mathrm{X}_{\mathrm{t}}\right)$ & $\begin{array}{l}\text { Total } \\
\text { tourist }\end{array}$ & $\begin{array}{l}\text { Pilgrimage } \\
\text { tourist }\end{array}$ & $\begin{array}{l}\text { As \% of } \\
\text { total }\left(\mathrm{Y}_{\mathrm{t}}\right)\end{array}$ & $\hat{\mathrm{Y}}_{\mathrm{t}}$ & $\mathrm{X}^{\prime}$ & $\mathrm{Y}^{\prime}$ & $\hat{\mathrm{Y}}_{\mathrm{t}}{ }^{\prime}$ \\
\hline $1992(1)$ & 334353 & 7219 & 2.2 & -0.8 & - & - & - \\
$1993(2)$ & 293567 & 10429 & 3.6 & 0 & 1.42 & 2.32 & 1.64 \\
$1994(3)$ & 326531 & 5475 & 1.7 & 0.8 & 1.84 & 0.39 & 1.84 \\
$1995(4)$ & 363395 & 5257 & 1.4 & 1.6 & 2.26 & 0.41 & 2.03 \\
$1996(5)$ & 393613 & 4802 & 1.2 & 2.4 & 2.68 & 0.39 & 2.22 \\
$1997(6)$ & 421857 & 4068 & 1.0 & 3.2 & 3.10 & 0.30 & 2.42 \\
$1998(7)$ & 463684 & 16164 & 3.4 & 4.0 & 3.52 & 2.82 & 2.61 \\
$1999(8)$ & 491504 & 19198 & 3.9 & 4.8 & 3.94 & 1.93 & 2.80 \\
$2000(9)$ & 463646 & 15801 & 3.4 & 5.6 & 4.36 & 1.14 & 3.00 \\
$2001(10)$ & 361237 & 13816 & 3.8 & 6.4 & 4.78 & 1.93 & 3.19 \\
$2002(11)$ & 275468 & 12366 & 4.5 & 7.2 & 5.20 & 2.30 & 3.38 \\
$2003(12)$ & 338132 & 21395 & 6.3 & 8.0 & 5.62 & 3.69 & 3.58 \\
$2004(13)$ & 385297 & 45664 & 11.9 & 8.8 & 6.04 & 8.25 & 3.77 \\
$2005(14)$ & 375398 & 47621 & 12.7 & 9.6 & 6.46 & 5.80 & 3.96 \\
$2006(15)$ & 383926 & 59298 & 15.4 & 10.4 & 6.88 & 8.03 & 4.15 \\
$2007(16)$ & 526705 & 52594 & 10.0 & 11.2 & 7.30 & 1.07 & 4.35 \\
$2008(17)$ & 500277 & 45091 & 9.0 & 12.0 & 9.28 & 3.20 & 5.26 \\
$2009(18)$ & 509956 & 51542 & 10.1 & 12.8 & 8.14 & 4.88 & 4.73 \\
$2010(19)$ & 602867 & 101335 & 16.8 & 13.6 & 8.56 & 10.94 & 4.93 \\
\hline
\end{tabular}

Sources: Data adapted and calculated from Economic Survey Fiscal Year 2008/09, Table 8.16, 78 and Economic Survey Fiscal Year 2068/69, Table 9.4, 89. 


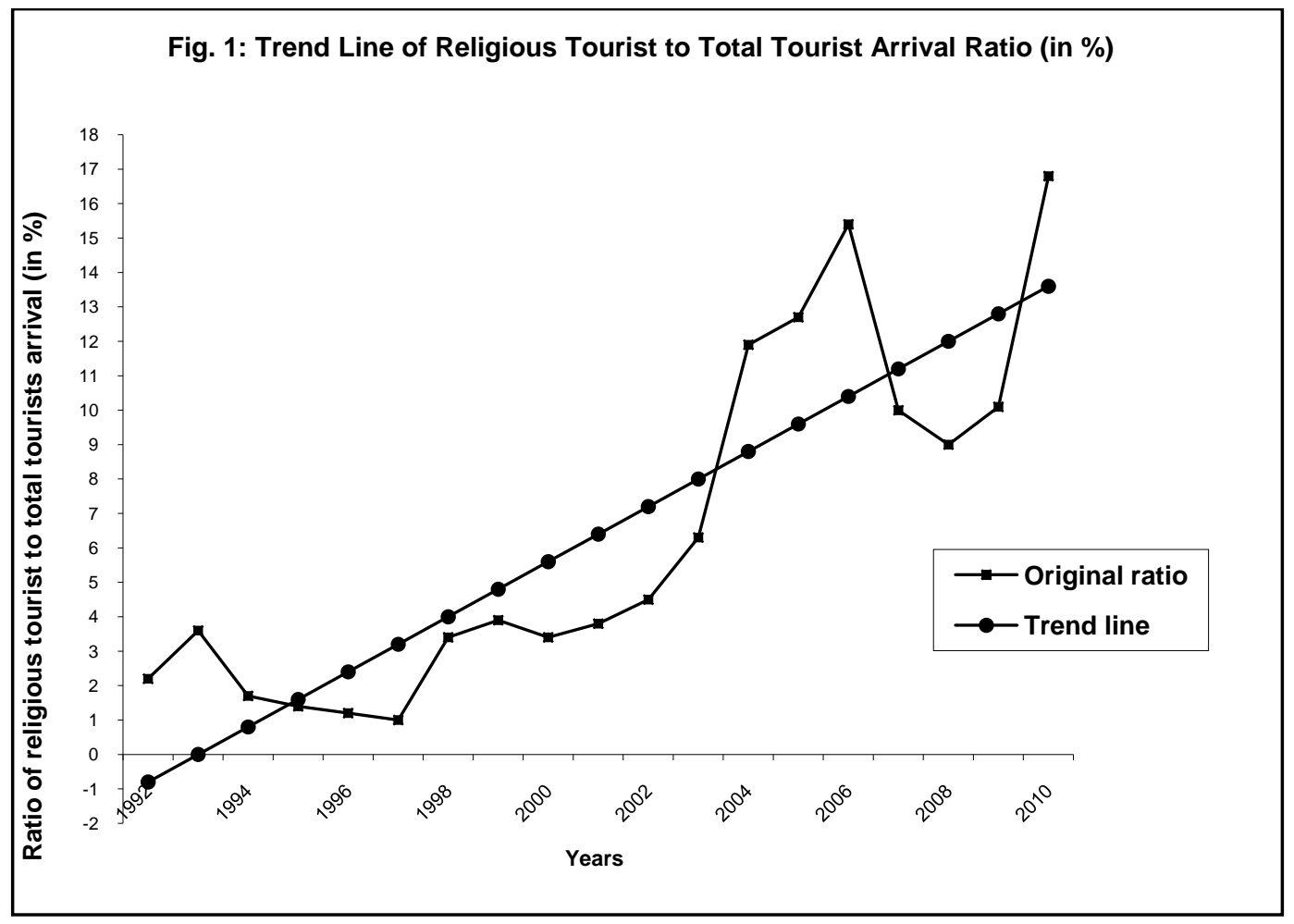

The coefficient of auto-correlation among error terms is 0.58 . The value of D-W statistic is 0.963 , which is less than $d_{L}=1.180$ at 5 percent level of significance with $k^{\prime}=1$ and $n=19$. Therefore, it is concluded that there is existence of positive auto-correlation among error terms. To remove the auto-correlation, the transformed equation of straight line is estimated as $\hat{\mathrm{Y}}_{\mathrm{t}}{ }^{\prime}=0.99+0.46 \mathrm{X}_{\mathrm{t}}{ }^{\prime}$. It shows that annual growth rate of religious tourist to total tourist arrival ratio is 0.46 percent. After the transformed the data, the auto-correlation among error terms is 0.21 and value of D-W statistics is 1.240 , which is greater than $\mathrm{d}_{U}$ (1.118) and less than $4-\mathrm{d}_{\mathrm{U}}$ (2.882) i.e., $\mathrm{d}_{\mathrm{U}}<\mathrm{d}<4-\mathrm{d}_{\mathrm{U}}$, which is closer to ' 2 '. Therefore, it is concluded that the error terms are independent and there is no auto-correlation among error terms. Therefore, it is concluded that presence of auto-correlation has been removed after transforming the data.

\section{CONLUSION}

From the analysis of data, it is apparent that religious tourist to total tourist arrival ratio has been oscillated during study period. The annual growth rate of religious tourist to total tourist arrival ratio is significant. Likewise, there is existence of auto-correlation among error terms during same period. The annul growth rate of this ratio after transforming the data has been found to decline in comparison to original data. After transforming the original data, it is found that there is no existence of auto-correlation among error terms and these terms are independent. Hence, it is recommended that more efforts should 
An Analysis of Religious Tourist Growth .... /25

be made to improve swiftly the religious tourist arrival emission in forthcoming time, which helps to generate foreign exchange earning ffrom tourism..

\section{REFERENCES}

Adhikari, L. (2069). "Tourism Prospect in the Chitwan National Park Area". Pragya Prabhat, Vol. 4:203-207.

Gurung, J.B. (2010). "Tourism in Nepal: Arrivals, Earnings and Employment", Economic Literature, Vol. IX: 105-115.

Ministry of Finance (2009). Economic Survey Fiscal Year 2008/09. Kathmandu: Ministry of Finance, Government of Nepal.

------(2069). Economic Survey Fiscal Year 2068/69, Kathmandu: Ministry of Finance,Government of Nepal.

Poudyal, S. (2012). "Does Tourims Really Matter for Eccoomic Growth? Evidence from Nepal", NRB Economic Review, Vol. 24(1 ): 48-66.

Shakya, K. (2008). "Tourism-Yesterday, Today and Tomorrow", Rural Tourism, ed. R. P. Upadhyay, Kathmandu: Sunlight Publication, pp.31-42.

Sharma, Om P. (2013).The System of Tourism Development Planning in Nepal (An Integrated Approach), (Second ed.), Kathmandu: Nawaraj Pandey, Anand Chand, Saraswati Sharma

Singh, S.P., A.K. Parashar, and H. P. Singh (1977). Econometrics and Mathematical Economics. New Delhi: S. Chand and Company Limited.

Srivastava, N.L. and Baral, P. (2010). "State and Prospects of Tourism Development in Lekhnath Municipality, Kaski", Economic Literature, Vol.IX :1-12.

Thapa, K.R. (2012). "Cultural Tourism for Sustainable Development", Economic Literature, Vol.X: 2732. 